Ana Knežević Bojović, PhD*

Olivera Purić, PhD $^{* *}$

Original scientific paper

UDC: 347.962

doi: 10.5937/spz0-20572

\title{
JUDICIAL TRAINING AND EU LAW: A VIEW ON COMPARATIVE AND SERBIAN PRACTICE
}

\author{
Abstract
}

EU law is a pivotal issue in modern-day judicial education in Europe. It is particularly important to ensure that, prior to EU accession, the judges of the acceding country are adequately trained on the fundamentals of EU law and its relation with national law and the role of the national judge in the European judicial space. Once a country becomes an EU member state, it is necessary to continue with adequate training and support to proper implementation of EU acquis by national judges. There is no right or wrong way to incorporate EU law in judicial training, although some best practice examples have been identified in the practices of EU member states, both of those that have joined the EU relatively recently and of the "older" EU member states.

The authors will investigate the practices related to judicial training on EU law in Serbia in the light of good comparative practices of judicial training institutions in Europe and formulate recommendations for Serbia in the context of EU accession.

Keywords: European Union, judicial training, independence, competence, comparative practices.

\section{Judicial competence a key element of judicial independence}

Judicial independence is a requirement stemming from the right to an effective remedy before a tribunal enshrined in a number of international documents related to the judiciary. It guarantees the fairness,

\footnotetext{
${ }^{*}$ Research Fellow, Institute of Comparative Law, Belgrade, e-mail: a.bojovic@iup.rs.

Advisor, Judicial Academy, Serbia, e-mail: puriceva10@gmail.com.
} 
predictability and certainty of the legal system. ${ }^{1}$ Judicial education and training are an essential element of judicial independence, as they help to ensure the competency of the judiciary. In an age that increasingly demands more judicial independence and competence needed to solve the complex and sensitive issues that arise in court cases, the need for judicial education is greater than ever.

This position, as Thomas underlines, ${ }^{2}$ is particularly common in European continental-law countries, and is supported by the idea that training helps to ensure the competency of the judiciary. It is possible to take this claim even further - when one thinks of a model of education of judges, one also necessarily thinks of desired model of a judge or a prosecutor. ${ }^{3}$ To contemplate an ideal model of a judge or a public prosecutor also implies the obligation of contemplating the ideal of a society one wishes to build, of considering its political, economic and social organisation, and of the system of checks and balances. ${ }^{4}$ Judicial independence and judicial education are intrinsically related.

Several international instruments recognise the importance of judicial independence and hence judicial education and training, including Article 6 of the Convention for the Protection of Human Rights and Fundamental Freedoms, ${ }^{5}$ and Article 14 of the International Covenant on Civil and Political Rights, ${ }^{6}$ as well the United Nations Basic Principles on the Independence of the Judiciary of $1985 .{ }^{7}$

\footnotetext{
${ }^{1}$ Communication from the Commission to the European Parliament, the Council, the European Central Bank, the European Economic and Social Committee and the Committee of the Regions - The 2017 EU Justice Scoreboard, COM(2017) 167 final, 37, https://ec.europa.eu/info/sites/info/files/justice scoreboard 2017 en.pdf, last visited 30 March, 2018. The EU justice scoreboard provides comparable data on the independence, quality, and efficiency of national justice systems. It is an information tool that helps the EU achieve more effective justice. The scoreboard mainly focusses on civil, commercial and administrative cases to pave the way for a more investment, business and citizen-friendly environment.

${ }^{2}$ C. Thomas, Review of Judicial Training and Education in Other Jurisdictions, 13, https://www.ucl.ac.uk/ judicial-institute/sites/judicial-institute/files/judicial_training_and_education_in_other_jurisdictions.pdf, last visited October 30, 2018.

${ }^{3}$ A. Knežević Bojović, O. Purić, "In-service Training of Judges in Europe”, Strani pravni život 4/2016, 57-70.

${ }^{4}$ A. Cluny, Training of judges and public prosecutors in the function of quality of judicial system, Judge's Association of Serbia, Belgrade 2015, 17.

${ }^{5}$ Council of Europe, European Convention for the Protection of Human Rights and Fundamental Freedoms, as amended by Protocols Nos. 11 and 14, 4 November 1950, https://rm.coe.int/1680063765, last visited December 15, 2018.

${ }^{6}$ United Nations, International Covenant on Civil and Political Rights Adopted and opened for signature, ratification and accession by General Assembly resolution 2200A (XXI) of 16 December 1966, entry into force 23 March 1976, in accordance with Article 49, https://www.ohchr.org/Documents/ProfessionalInterest/ccpr.pdf, last visited December 15, 2018.

${ }^{7}$ United Nations, Basic Principles on the Independence of the Judiciary Adopted by the Seventh United Nations Congress on the Prevention of Crime and the Treatment of Offenders held at Milan from 26 August to 6 September 1985 and endorsed by General Assembly resolutions 40/32 of 29 November 1985 and 40/146 of 13 December 1985, https://www.ohchrorg/en/professionalinterest/pages/independencejudiciary. aspx, last visited December 15, 2018.
} 
In addition, a number of regional framework documents also provide guidance to states on their obligations with respect to judicial training - among these the European framework is of particular interest.

The European Charter on the Statute of Judges of 1998 makes direct references to the level and scope of appropriate training that judges should receive both prior to the service and in-service. ${ }^{8}$ The Council of Europe has also developed a set of instruments governing key aspects for establishing an efficient system of education and training of judges. These include:

- Committee of Ministers Recommendation No. (2010) 12 on Judges independence, efficiency and responsibilities ${ }^{9}-$ in its section 56 the Recommendation states that judges should be provided with theoretical and practical in-service training, entirely funded by the state, which should include economic, social and cultural issues related to the exercise of judicial function;

- Recommendation No. (2004) 4 on the European Convention on Human Rights in university education and professional training, ${ }^{10}$ recommending that training concerning the Convention and the case-law of the Court exist at national level as a component of the continuous training provided to judges, prosecutors and lawyers;

- Opinions of the Consultative Council of European Judges (CCJE) No. $1^{11}$ (2001) and No. 3 (2002) $)^{12}$ and, most importantly, Opinion No. 4 (2003) of Consultative Council of European Judges (CCJE) on appropriate initial

\footnotetext{
${ }^{8}$ Council of Europe, European Charter on the statute of judges, 1998, https://rm.coe.int/16807473ef, last visited December 15, 2018. Articles 2.3, 4.4 of the Charter. The explanatory memorandum to the Charter underlines that judges "must have regular access to training organized at public expense, aimed at ensuring that judges can maintain and improve their technical, social and cultural skills..."

${ }^{9}$ Recommendation CM/Rec(2010)12 of the Committee of Ministers to member states on judges: independence, efficiency and responsibilities (Adopted by the Committee of Ministers on 17 November 2010 at the 1098th meeting of the Ministers' Deputies), https://rm.coe.int/16807096cl, last visited December 15, 2018. ${ }_{10} \mathrm{https}: / /$ search.coe.int/cm/Pages/result_details.aspx?OObjectID $=09000016805 \mathrm{dd} 13 \mathrm{a}$, last visited December $15,2018$.

${ }^{11}$ Opinion No 1 (2001) of The Consultative Council of European Judges (CCJE) for the attention of the Council of Europe on standards concerning the independence of the judiciary and the irremovability of judges (Recommendation no. R (94) 12 on the independence, efficiency and role of judges and the relevance of its standards and any other international standards to current problems in these fields), Strasbourg, 23 November 2001, https://rm.coe.int/1680747830, last visited December 15, 2018.

12 Opinion no. 3 of the Consultative Council of European Judges (CCJE) to the attention of the Committee of Ministers of the Council of Europe on the principles and rules governing judges' professional conduct, in particular ethics, incompatible behaviour and impartiality. It states that the effectiveness of the judicial system also requires judges to have a high degree of professional awareness, and that judges are required to ensure maintain a high degree of professional competence through basic and further training, Strasbourg, 19 November 2002, https://rm.coe.int/168070098d, last visited December 15, 2018.
} 
and in-service training. ${ }^{13}$ The need for the independence of judicial training institutions, the importance of appropriate training for young judges, particularly focused on the acquisition of skills and "judgecraft" qualities, as well as the recognition of time spent on training as an investment in the quality of justice, are amongst the core principles enshrined in these instruments;

- Recently, on 28 June 2016, the General Assembly of the European Judicial Training Network adopted Nine Principles of Judicial Training. ${ }^{14}$ The principles establish key statements relating to the nature of judicial training, the importance of initial training, the right to regular continuous training and the integral nature of training in daily work. The principles also address the scope of competences of national training institutions regarding the content and delivery of training, clarify who should deliver training and stress the need for modern training techniques. Moreover, the principles underscore the need for funding of judicial training and support commitments from authorities. ${ }^{15}$

Institutionalised initial and continuous training of judicial office holders is a long standing tradition in some European countries, such as France ${ }^{16}$, Spain ${ }^{17}$ and Germany ${ }^{18}$. On the other hand, new Central and East European EU member states have had a different legal tradition regarding judicial independence and judicial education and training ${ }^{19}$ - however, these traditions and practices seem to be converging in the past years. ${ }^{20}$

\footnotetext{
${ }^{13}$ Opinion No 4 of the Consultative Council of European Judges (CCJE) to the attention of the Committee of Ministers of the Council of Europe on appropriate initial and in-service training for judges at national and European levels, Strasbourg, 27 November 2003, https://rm.coe.int/1680747d37, last visited December 15, 2018.

${ }^{14}$ EJTN, Judicial training principles, http://www.ejtn.eu/PageFiles/15004/Judicial\%20Training\%20Principles_EN.pdf, last visited March 25, 2018.

${ }^{15}$ Ibid.

${ }^{16}$ For more information see: J. P. Reichert, "Recruiting and Training Judges in France”, Judicature, Vol. 57 , 4/1973, 145-149.

${ }^{17}$ L. Muniz-Argüelles, M. Fraticelli-Torre, "Selection and Training of Judges in Spain, France, West Germany, and England", Boston College International and Comparative Law Review, Vol. 8, 1/1985, 1-37.

18 Ibid.

${ }^{19}$ On challenges of judicial independence in these countries see, in particular: C. Dallara, "Judicial Reforms in SEE Democratising Countries. Towards a Contextualized Framework for the Analysis", in: Democracy and Judicial Reforms in South-East Europe: Between the EU and the Legacies of the Past, Springer International Publishing, 2014, 1-30; D. Kosař, Perils of Judicial Self-Government in Transitional Societies: Holding the Least Accountable Branch to Account, Cambridge University Press, 2016; Z. Kühn, The Judiciary in Central and Eastern Europe: Mechanical Jurisprudence in Transformation?, Brill, 2011.

${ }^{20}$ C. Thomas, op. cit.
} 


\section{Judges and European Union Law}

European law has submerged domestic laws in EU member states, ${ }^{21}$ in a framework of progressively Europeanized national legal sources. ${ }^{22}$ This is due to the overwhelming number of EU legislative acts, which touch upon virtually every field of law. In addition, effective application of European Union law cannot be ensured by the European Union and its courts alone - it depends strongly on domestic courts and individuals that initiate proceedings before these courts to enforce their rights under European Union law. ${ }^{23}$ EU law must be applied by the domestic judge because it enjoys precedence over internal law. ${ }^{24}$ EU law can also have indirect effects because all provisions of domestic law must be interpreted, so far as possible, in a way that enables achievement of the result sought through the relevant EU law. ${ }^{25}$ Finally, EU law requires effective judicial protection, which means that if EU law creates rights, member states must provide access to courts to enforce these rights. ${ }^{26}$ The doctrines of primacy and direct effect of EU law, harmonious interpretation, effectiveness, and the preliminary ruling procedure allow national judges to undertake judicial actions normally not permitted under national law, while at the same requiring from them a thorough knowledge of EU law.

However, various studies illustrate that national judges are frequently critical of their familiarity with EU law and that they often experience difficulties with resorting to and applying EU law. ${ }^{27}$ This clearly demonstrates the need to advance the knowledge of EU law within national judicial systems, in order to ensure its effective application.

Recognising the importance of judicial training in EU law, the European Commission published a Communication on "Building trust

\footnotetext{
${ }^{21}$ EJTN, Handbook on Judicial Training Methodology in Europe, 18 www.ejtn.eu/Documents/EJTN_JTM Handbook_2016.pdf, last visited March 31, 2018.

${ }^{22}$ See J. A. Mayoral, U. Jaremba, T. Nowak, "Creating EU law judges: the role of generational differences, legal education and judicial career paths in national judges' assessment regarding EU law knowledge", Journal of European Public Policy, Vol. 21, 8/2014, 1121; M. Eliantonio, Europeanisation of Administrative Justice? The Influence of the ECJ's Case Law in Italy, Germany, and England, Europa Law Publishing, 2008; W. C. Muller et al., "Legal Europeanization: comparative perspectives", Public Administration, Vol. $88,1 / 2010,75-87$.

${ }^{23}$ Case 26/62 Van Gend \& Loos [1963] ECR 1. See: P. Craig, C. de Burca, EU Law Text, Cases and Materials, Oxford University Press, 2011, 181 et seq.

${ }^{24}$ Case 6/64 Costa v Enel [1964] ECR 585; Case C 409/06 Winner Wetten [2010] ECR I 8015, par. 53.

25 Joined Cases C 397/01 to C 403/01 Pfeiffer and Others [2004] ECR I 8835; Case C 282/10 Dominguez [2012] ECR I 0000.

${ }^{26}$ Case 222/86 Heylens and others [1987] ECR 4097; Case C 240/09 Lesoochranárske zoskupenie [2011] ECR I 1255, par. 48-51.
}

27 J. A. Mayoral, U. Jaremba, T. Nowak, 1121. 
in EU-wide justice, a new dimension to European judicial training" in September 2011. ${ }^{28}$ The aim of this Communication was to give a new dimension to European judicial training and to enable an even greater number of legal practitioners to access high-quality training in European Union law. According to data provided in the European Parliament's Study "Judicial training in the European Union Member States" 29 the preliminary results of which have informed the Communication, in 2011, $42 \%$ of judges and $56 \%$ of prosecutors declared that they had never participated in judicial training on EU or another Member State's law, while $76 \%$ of judges and $73 \%$ of prosecutors declared that the number of cases involving EU law had increased over the years. $31 \%$ of respondents had never attended training on EU law because no such training had been available. ${ }^{30}$ In the Communication, the Commission has set the target of enabling half of the legal practitioners in the European Union - therefore not just judges and prosecutors, but also lawyers, solicitors, barristers, notaries and other legal practitioners - to participate in European judicial training activities by 2020 through the use of available resources at local, national and European level. The Communication offers guidance on how to ensure the attainment of this target, expressly referring to increased number of trainings on EU law, but also to improvement of language skills, e-learning and development of the e-justice portal.

The Commission has taken concrete steps within its purview in a continued commitment to this objective, including:

- increasing the funding available for European judicial training;

- support to AIAKOS,,${ }^{31}$ a two-week exchange programme for new judges and prosecutors, managed by the European Judicial Training Network;

- development of training modules on the implementation of specific European legislative instruments, which are available free of charge and can be adapted to national contexts. ${ }^{32}$

\footnotetext{
${ }^{28}$ Communication from The Commission to the European Parliament, the Council, the European Economic and Social Committee and the Committee of the Regions Building Trust In EU-Wide Justice a New Dimension To European Judicial Training, COM/2011/0551 final.

${ }^{29}$ See at: http://www.europarleuropa.eu/RegData/etudes/etudes/join/2011/453198/IPOL-JURI_ET(2011)453198_ EN.pdf, last visited December 15, 2018.

${ }^{30}$ Ibid., 116-120.

31 EJTN, AIAKOS Programme, http://www.ejtn.eu/Exchange-Programme/Activities/AIAKOS-Programme/, last visited March 30, 2018.

32 The materials are available at: https://e-justice.europa.eu/content_training_material-252-en.do?clang=en, last visited March 29, 2018.
} 


\section{Comparative approaches to judicial training on EU law in $\mathrm{EU}$ Member States}

Comparative experience shows that the approach to judicial training on EU law in European Union member states is not uniform. It is important to note that there is no right or wrong way to incorporate EU law in judicial training, although some best practice examples have been identified. ${ }^{33}$ These best practices feature multi-faceted approaches to training in EU law, which sometimes combine face-to-face and distance learning methods.

In EU law countries, training on EU law is organised both in the form of special seminars dedicated to specific areas of EU law, e.g. the European judicial space in the field of social security, or harmonisation of labour and social security national laws with the acquis, or as an integral part of training on given issues, e.g. intellectual property law, where the relevant sources of EU law are also covered. In Poland, for instance, EU law is an integral part of trainings on other topics, but there are also separate seminars dealing with EU law issues, such as mutual legal assistance in civil matters, a seminar on consequences of EU membership for judges, etc. ${ }^{34}$ Similarly, the Spanish continuous training curriculum for judges offers a set of trainings on the application of EU law and seminars focusing on legal linguistics of EU law. ${ }^{35}$ In Italy, a network of local trainers who are competent to address training needs in EU and ECHR law is formed to support judges in applying EU law. ${ }^{36}$

In the Netherlands, all judicial training materials that incorporate information on EU law are clearly marked with an EU flag, so as to increase the visibility of EU law in judicial training. ${ }^{37}$

When it comes to countries that have joined the EU relatively recently, the focus of training on EU law has shifted from raising awareness on EU law and providing access to information, to integrating EU law in courses on domestic substantive law and enabling judges and prosecutors to apply EU law and its instruments in their daily practice.

\footnotetext{
${ }^{33}$ European Commission, Final Report - Tender JUST/2 012/JUTR /PR/0064/ A4 Lot 1 "Study on best practices in training of judges and prosecutors", 2014, http://www.ejtn.eu/Documents/Resources/Lot1_final Jan2015.pdf, last visited March 27, 2018.

34 The EP Pilot Project on European Judicial Training (material provided by courtesy of Serbian Judicial Academy).

${ }^{35}$ Ibid.

${ }^{36}$ A. Knežević Bojović, Comparative analysis of judicial training curricula, 2018, 25, https://www.pars.rs/ images/projekti/JAP/Komponenta-2/A4_IIR-Comparative-analysis-of-judicial-training-curricula-Uporedna-analiza-programa-obuke-nosilaca-pravosudnih-funkcija.pdf, last visited December 14, 2018.

${ }^{37}$ Ibid.
} 
For instance, in Bulgaria, training activities on EU law and international judicial co-operation are complemented by provision of access to resources and up-to-date information through a digital platform. This approach was also followed in Romania. Similar practices are present in the Czech Republic and Portugal. ${ }^{38}$ In addition, a network of "judge coordinators" on EU law was established in Bulgaria - these judges act as key reference points for their colleagues with regard to finding specific information or applying EU law. The Croatian continuous training curriculum offers specialised courses on various aspects of EU law, including EU civil procedure, EU bankruptcy and enforcement procedure, judicial cooperation in civil and criminal cases, and the like. ${ }^{39}$

Another good example of a multi-faceted and integrated approach was pursued by the four countries of the Visegrad group (Hungary, Czech Republic, Poland and Slovakia), which have organised joint trainings for judges and prosecutors from neighbouring countries/regions in EU law. ${ }^{40}$

\section{EU law and Judges in Accession Countries}

Rule of law principle is considered to be a core pillar of the European Union and by implication a core benchmark for accession by candidate countries. Rule of law is not only one of the basic values of the European Union, but also one of the fundamental principles of the member states' legal systems, a part of what the European Court of Justice sees as the "European constitutional heritage". ${ }^{41}$

When it comes to accession, the idea is that the process is not only about shared values, but also about shared practices: the existence of states capable of not only adopting, but also enforcing EU laws or EU-compatible national laws. The principle of legality in the performance of governments, including public administration and judiciary, underpins both the political and economic stability of any aspiring member state.

On February 6, 2018, the European Commission adopted a strategy document entitled "A credible enlargement perspective for an enhanced EU

\footnotetext{
${ }^{38}$ Ibid., 24. For details on Romanian approach see: http://www.ejtn.eu/Documents/Methodologies Resources/ Best\%20practices\%20Lot\%201\%20EN/ITT UP\%2003 Romania EU en\%20(2).pdf, last visited December 14, 2018. For Portugal see: http://www.ejtn.eu/Documents/Methodologies Resources/Best\%20practices\%20 Lot\%201\%20EN/ITT UP\%2002 Portugal EU en\%20(2).pdf, last visited December 14, 2018.

${ }^{39}$ A. Knežević Bojović, 24.

40 http://www.ejtn.eu/Documents/Methodologies Resources/Best\%20practices\%20Lot\%201\%20EN/ITT 39-I Hungary 1 EU en.pdf, last visited December 14, 2018.

${ }^{4 \Gamma}$ K. Nicolaidis, R. Kleinfeld, Rethinking Europe's "Rule of Law" and Enlargement Agenda: The Fundamental Dilemma, SIGMA Paper No. 49, 8, www.sigmaweb.org/publicationsdocuments/sigma sp49 061112 Eng. $p d f$, last visited March 15, 2018.
} 
engagement with the Western Balkans". ${ }^{42}$ The strategy confirms the European future of the region, but at the same urges the Western Balkans countries to redouble their efforts, address vital reforms and complete their political, economic and social transformation. Rule of law and fundamental rights are identified as the most pressing issue, and it is underlined that rule of law is not only an institutional issue, but that it requires societal transformation. More specifically, the Strategy underlines that the independence of the judiciary and of individual judges is essential to ensure fairness and to hold the executive and legislative branches of government to account, as a precondition for any democratic society based on the rule of law and for its economic development. The Strategy refers to 2025 as the earliest possible date for accession. On May 17, 2018, EU leaders issued the Sofia Declaration ${ }^{43}$ of the EU-Western Balkans summit, reaffirming their support to the European perspective of the Western Balkans. The political momentum of this Summit was somewhat undermined by the statement of the French President Emmanuel Macron about the need for performing an internal EU reform prior to the next enlargement round. President Macron was explicit in saying that "The past 15 years have shown the path of weakening Europe, while we have been working on its expansion all the time. We will not do the service neither to the candidate countries nor to us if we have a mechanism that, in a way no longer has rules and keeps moving toward more enlargement." ${ }^{44}$ While this message may have created an unwelcome uncertainty as to the timeline of the next enlargement, it is nonetheless connected with the progress of candidate countries in the domain of the rule of law. This linkage is best captured by the statement of the EU Commissioner for European Neighbourhood Policy and Enlargement Negotiations, Johannes Hahn, of December 2017, that, "while speed matters, it is the quality of the reforms that counts". ${ }^{45}$

Within this framework, the relevance of EU law and the EU accession process for judges is threefold:

- Firstly, judges need to demonstrate competence and knowledge that will qualify them as future judges of a single EU judicial system;

- Secondly, judges need to be adequately prepared to implement the relevant principles of EU law, be acquainted with the preliminary ref-

\footnotetext{
${ }^{42}$ Communication from the Commission to the European Parliament, the Council, the European Economic and Social Committee and the Committee of the Regions A credible enlargement perspective for and enhanced EU engagement with the Western Balkans, Strasbourg, 6.2.2018, COM(2018) 65 final.

${ }^{43}$ https://www.consilium.europa.eu/media/34776/sofia-declaration en.pdf, last visited December 1, 2018.

44 https://europeanwesternbalkans.com/2018/05/25/macron-eu-enlargement-cold-water-warm-bath/, last visited December 1, 2018.

45 https://www.b92.net/info/vesti/index.php?yyyy $=2017 \& m m=12 \& d d=12 \&$ nav_category $=1262 \&$ nav $i d=1335158$, last visited December 1, 2018.
} 
erence procedure and also with substantive EU law in their respective areas of professional interest, in order to correctly apply the principles related to EU acquis once the country becomes an EU member state;

- Thirdly, judges may find themselves in the position to apply provisions of EU law even in the course of the accession process, either by virtue of the provisions of the Stabilisation and Association Agreement that call for implementation of EU acquis or the provisions calling for a proper implementation and enforcement of legislation that is compatible with EU acquis. ${ }^{46}$

Countries wishing to join the European Union tackle this challenge differently, and in line with their respective judicial training traditions and practices, within the framework of general judicial education. This may result in side-lining of judicial education on EU law issues - the majority of training is dedicated to the national law subjects, given the intensive legislative demands related to harmonisation with EU law, but also related to inherent needs for reforms in various legal areas which may not always be accession-driven. In this paper we will demonstrate this observation on the example of Serbia, currently a front-runner for EU accession.

\section{Judicial training on EU law in Serbia}

When it comes to judicial training, Serbian regulatory framework ${ }^{47}$ does not envisage compulsory in-service training for judges.

Continuous training is provided by the Judicial Academy, but the majority of programmes are organised on ad hoc basis and financed from donor funds. In an attempt to coordinate various donor initiatives, steering

${ }^{46}$ Stabilization and Association Agreement between the European Communities and their Member States of the one part, and the Republic of Serbia, of the other part, for instance, prescribes in Article 73, paragraph 2: "Any practices contrary to this Article shall be assessed on the basis of criteria arising from the application of the competition rules applicable in the Community, in particular from Articles 81, 82, 86 and 87 of the EC Treaty and interpretative instruments adopted by the Community institutions.". In addition, Article 72, paragraph 1 of this Agreement states: "Serbia shall endeavor to ensure that its existing laws and future legislation will be gradually made compatible with the Community acquis. Serbia shall ensure that existing and future legislation will be properly implemented and enforced" (emphasis added). The obligation to proper implementation lies, inter alia, on courts and judges. For a more detailed analysis see: M. Stanivuković, "Pravo Evropske unije i sudovi u Srbiji”, Zbornik radova Pravnog fakulteta, Novi Sad, Vol. 46, 1/2012, 203-221.

${ }^{47}$ Law on judges, Official Gazette of the Republic of Serbia, No. 116/2008, 58/2009 - decisions of the Constitutional Court, 104/2009, 101/2010, 8/2012 - decisions of the Constitutional Court, 121/2012, 124/2012 - decisions of the Constitutional Court, 101/2013, 111/2014 - decisions of the Constitutional Court 117/2014, 40/2015, 63/2015 - decisions of the Constitutional Court and 106/2015; Law on Public Prosecution, Official Gazette of the Republic of Serbia, No. 116/2008, 104/2009, 101/2010, 78/2011 - other law, 101/2011, 38/2012 - decisions of the Constitutional Court, 121/2012, 101/2013, 111/2014 - decisions of the Constitutional Court, 117/2014 and 106/2015; Law on High Judicial Council, Official Gazette of the Republic of Serbia, No. 116/2008, 101/2010, 88/2011 and 106/2015); Law on State Prosecutorial Council, Official Gazette of the Republic of Serbia, No. 116/2008, 101/2010, 88/2011 and 106/2015; Decision on Changes and Amendments to the Rules of Procedure of High Judicial Council, Official Gazette of the Republic of Serbia, No. 29/13. 
them towards development and delivery of trainings that are instrumental for improving the quality of judicial decisions and processes and ensuring responsiveness to the needs of the Serbian judicial system, the Judicial Academy has adopted a set of measures aimed at improving the overall quality of judicial training. One such mechanism was the adoption of a Rulebook on Training Need Assessment in early 2017, its piloting in 2017 and the development of the 2018 Judicial Academy Continuous Training Curriculum, informed by this exercise. ${ }^{48}$ The training curriculum for 2019, recently adopted by the Judicial Academy, is also informed by a TNA conducted according to the Rulebook.

As a result of this systemic effort, EU law is recognised as a priority training subject for judges of all instances. When it comes to specific topics, the following figure shows the priorities in training on EU law as identified by Serbian judges and prosecutors:

\section{EU Law}

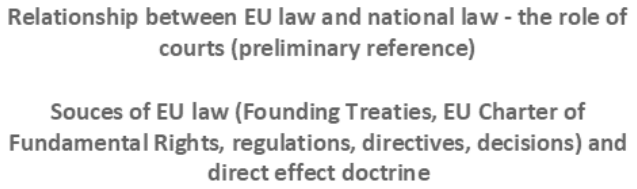

Souces of EU law (Founding Treaties, EU Charter of Fundamental Rights, regulations, directives, decisions) and direct effect doctrine

Judicial cooperation in civil matters

EU judicial system

Judicial cooperation in criminal matters

EU institution

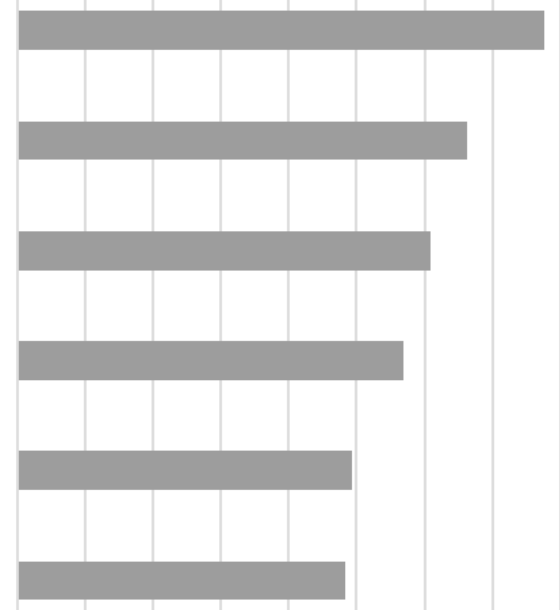

Figure 1: Cross-comparison of results for courts of general jurisdiction and commercial courts of all instances and Administrative Court ${ }^{49}$

The TNA has further identified that one of the constant challenges the Serbian JA faces is the need to organise and deliver large-scale trainings related to introduction of new laws. These trainings consume a considerable

\footnotetext{
${ }^{48}$ Results of the TNA are available at O. Purić, A. Knežević Bojović, Training needs assessment for the Serbian Judicial Academy Results and recommendations, 2018, https://www.pars.rs/images/projekti/JAP/ Komponenta-2/A5_3IR-TNA-for-the-Serbian-JA-Results-and-recommendations-no.-2-TNA-u-okviru-PAu-RS-br.-2--rezulati-i-preporuke.pdf, last visited December 14, 2018.

${ }^{49}$ Ibid., 18.
} 
portion of the JA resources and shift the focus from other topics. It therefore called on the JA to recognise the need for ensuring continuous training on a variety of topics, using different training methods at both basic and advanced knowledge levels, ensuring a multi-faceted approach to training wherever possible. ${ }^{50} \mathrm{EU}$ law is a subject that is particularly well-suited for such an exercise, combining different topics and methodologies.

Responding to the identified needs, the Judicial Academy has launched as systemic approach to judicial training on EU law in 2017 and 2018.

Firstly, a comprehensive EU training curriculum was developed for "Fundamentals of EU law" and four trainings have been delivered to judges and advisors of the Supreme Court of Cassation and appellate court judges of all four Serbian appellate courts. In addition, three advancedlevel curricula have been developed for EU Civil Law, EU Criminal Law and EU Administrative Law, followed by a training of trainers for the three mentioned curricula in the first half of 2018.

Learning from best comparative practice examples, in early 2018, the Judicial Academy has set up a Network of National Judges and Prosecutors on European Standards of Judicial Protection of Human Rights. ${ }^{51}$ The network is envisaged as a peer-support mechanism focusing on Council of Europe and European Union standards of judicial protection of human rights. As the Network has been established only recently, it is still early to assess its impact on improving the competences of Serbian judges and prosecutors; however, given the positive experiences in comparative practice and the endorsement provided to its work by the High Judicial Council and the State Prosecutor's Council, it is reasonable to expect that the network will, at a minimum, ensure improved access to information related to EU law and the jurisprudence of the Court of Justice of the European Union related to human rights' protection, serving as an on-demand knowledge hub.

\section{Going forward}

As described above, in 2011 the European Commission set the target that by 2020 all legal practitioners in the EU should have attended training on EU law or on the law of another Member State. In 2016, more than 143000

\footnotetext{
${ }^{50} \mathrm{Ibid} ., 58$.

51 See at:

http://www.pars.rs/en/vest/5785/two-day-seminar-entitled-importance-of-the-implementation-of-the-standards-of-the-european-court-of-human-rights-in-the-republic-of-serbia-php, last visited March 27, 2018.
} 
EU legal practitioners received training on EU law or on the national law of another Member State. ${ }^{52}$ At the same time, EU legislation and EU case law are still growing and regular updates of knowledge need to be performed.

The EU Justice Scoreboard, a comparative information tool on national justice system of EU member states, enables monitoring the progress in judicial reforms and the functioning of the judicial systems in EU countries on an annual basis. The main elements for monitoring set out in the EU Justice Scoreboard are classified in the following three categories: Efficiency of the justice system, Quality of the justice system and Independence. One of the indicators used to assess the quality of the justice system is the percentage of judges participating in continuous training activities in EU law or in the law of another Member State. The results for 2018 show that most EU member states still have quite a long way to go before attaining the goal set in the above-mentioned communication:

Judges participationg in continuos training activities in EU law or in the law of another Member State (*) (as a percentage of total number of judges)

Source: European Commision

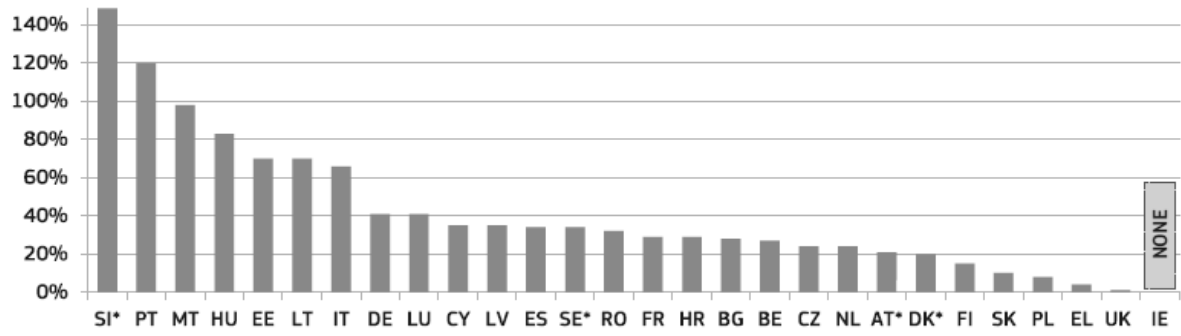

$\left(^{*}\right)$ Values of some Member States have been reduced for presentation purposes $(\mathrm{SI}=243 \%)$. In a few Member States the ratio of participants exceeds 100\%, meaning that some participants attended more than one training activity. DK: including court staff. AT: Including prosecutors. SE data are for 2015 .

Figure 2: Judges participating in continuous training activities in EU law or in the law of another Member State ${ }^{53}$

The information monitored in the EU Justice Scoreboard is important for Serbia for two reasons: firstly, the Scoreboard will become a monitoring tool for the Serbian judicial system once Serbia becomes an

\footnotetext{
${ }^{52}$ See at:

https://e-justice.europa.eu/content the european judicial training policy-121-en.do, last visited April 1, 2018.

${ }^{53}$ The EU Justice Scoreboard 2018, Communication from the Commission to the European Parliament, the Council, the European Central Bank, the European Economic and Social Committee and the Committee of the Regions COM(2018) 364 final, 34, https://ec.europa.eu/info/sites/info/files/justice_scoreboard_2018_ en.pdf, accessed on December 15, 2018.
} 
EU member state. Secondly, the Serbian Supreme Court of Cassation has already adopted this framework as a point of reference for their reporting. So how should Serbia continue forward with judicial training on EU law?

Thinking early of a comprehensive approach to judicial training on EU law can help ensure a smooth transition from an aspiring EU country to a full-fledged functional member state. In this vein, in the years preceding the EU accession, the judicial training institutions in accession countries should ensure that training on the fundamentals of EU law, such as the sources of EU law, the relationship between national law and EU law, the role of the national judge in implementing EU law, the preliminary reference and the principle of direct effect has as wide a coverage as possible, including judges and prosecutors at all levels. Serbian Judicial Academy has already taken steps in this direction; however, the effort needs to be intensified, while the percentage of judges who have already participated in some level of training on EU law should be identified to help guide the exercise.

Training on judicial cooperation in civil and criminal matters in EU law in accession countries, should also have wide coverage, as it can quickly become relevant and applicable. Furthermore, prior to accession, specialised and focused training on certain topics of EU law should be primarily offered to judges of commercial and administrative courts. Serbian Judicial Academy, as can be seen, is taking systemic steps towards ensuring that this recommendation is followed, and it is important for this momentum to be maintained.

As a general rule, the years preceding the EU accession should be used for training of trainers on EU law among holders of judicial offices in order to ensure sustainability and duly respond to EU's strategic approach to judicial training on acquis. These efforts need to be stepped up in Serbia.

It is commendable that among Western Balkan countries Serbia has pioneered the establishment of a network of judges and prosecutors who would be appointed as focal points on certain aspects of EU law, particularly given that this practice has proven to be a useful peer-topeer support mechanism, as outlined above in the text. Ideally, this effort should be further supported by the development of a platform enabling access to up-to-date materials on EU law for judges and prosecutors. Since the development of such a platform requires additional funding, this could be set as a further target for the Serbian Judicial Academy, which certainly seems intent on doing so.

Further recommendations for advancing judicial training on EU 
law that Serbian Judicial Academy should consider are the following:

- Training courses on EU law organised by ERA and EJTN should be offered to national judges, where economically feasible.

- Existing EU law curricula on general or specialised topics developed by European judicial training institutions could be utilised to deliver training on specific issues of EU law, e.g. the training modules on European Legislative instruments on cross-border cooperation in civil matters ${ }^{54}$ or on environmental law. ${ }^{55}$

- A regional approach to training on EU law, similar to that adopted by the Visegrad group judicial training institutions (e.g. joint trainings on could be considered as an innovative training method) could be utilised to facilitate and streamline training efforts.

- Training on EU law could be coupled with specialised linguistic training, as this simultaneously ensures full understanding of the key legal concepts and the linguistic nuances of eurojargon and acquis, applied to the national setting.

On its way towards the EU, Serbia is currently addressing the main needs of its judges related to knowledge of EU law. As the process continues to advance, so will the needs of the Serbian judiciary, and it is imperative for the Serbian judicial system to draw from the experiences of both „old“ and ,new" member states in defining the models for getting Serbian judges and prosecutors fully familiar with the EU law. The bar in the EU is raised high, and Serbia has to be ready to invest significant efforts to attain it and measure up to standards.

\section{References}

Cluny, A., Training of judges and public prosecutors in the function of quality of judicial system, Judge's Association of Serbia, Belgrade 2015.

Craig, P., de Burca C., EU Law Text, Cases and Materials, Oxford University Press, 2011.

Dallara, C., "Judicial Reforms in SEE Democratising Countries. Towards a Contextualized Framework for the Analysis", in: Democracy and Judicial Reforms in South-East Europe, Springer International Publishing, 2014, 1-30. Eliantonio, M. Europeanisation of Administrative Justice? The Influence of the ECJ's

\footnotetext{
${ }^{54}$ ERA, Training modules on the European legislative instruments for cross-border cooperation in civil matters, https://www.era-comm.eu/EU_Civil_Justice_Training_Modules/index_html, last visited April 1, 2018.

${ }_{55}$ European Commission, EU Environmental Law Training Package, http://ec.europa.eu/environment/legal/law/training package.htm, last visited March 31, 2018.
} 
Case Law in Italy, Germany and England, Europa Law Publishing, 2008.

Knežević Bojović, A., Purić, O., "In-service Training of Judges in Europe", Strani pravni život, 4/2016, 57-70.

Kosař, D. Perils of Judicial Self-Government in Transitional Societies: Holding the Least Accountable Branch to Account, Cambridge University Press, 2016.

Kühn, Z. The Judiciary in Central and Eastern Europe: Mechanical Jurisprudence in Transformation?, Brill, 2011.

Mayoral, J.A., Jaremba U., Nowak T. "Creating EU law judges: the role of generational differences, legal education and judicial career paths in national judges' assessment regarding EU law knowledge", Journal of European Public Policy, Vol. 21, 8/2014, 1120-1141.

Muller, W.C., Bovens M., Grønnegaard Christensen J., Jenny M., Yesilkagit K., "Legal Europeanization: comparative perspectives", Public Administration, Vol. 88, 1/2010, 75-87.

Muniz-Argüelles, L., Fraticelli-Torres M. "Selection and Training of Judges in Spain, France, West Germany, and England", Boston College International and Comparative Law Review, Vol. 8, 1/1985, 1-37.

Reichert, J. P., "Recruiting and Training Judges in France", Judicature, Vol. 57, 4/1973, 145-149.

Stanivuković, M., "Pravo Evropske unije i sudovi u Srbiji", Zbornik radova Pravnog fakulteta, Novi Sad, Vol. 46, 1/2012, 203-221.

The EP Pilot Project on European Judicial Training (provided by courtesy of Serbian Judicial Academy).

Training Needs Assessment for the Serbian Judicial Academy (provided by courtesy of the Serbian Judicial Academy).

\section{Legal sources}

Case 222/86 Heylens and others [1987] ECR 4097.

Case 26/62 Van Gend \& Loos [1963] ECR 1.

Case 6/64 Costa $v$ Enel [1964] ECR 585.

Case C 240/09 Lesoochranárske zoskupenie [2011] ECR I 1255.

Case C 282/10 Dominguez [2012] ECR I 0000.

Case C 409/06 Winner Wetten [2010] ECR I 8015.

Communication from the Commission to the European Parliament, the

Council, the European Central Bank, the European Economic and Social Committee and the Committee of the Regions - The 2017 EU Justice Scoreboard, COM(2017) 167 final, https://ec.europa. 
eu/info/sites/info/files/justice_scoreboard_2017_en.pdf, last visited 30 March, 2018.

Communication from The Commission to the European Parliament, the Council, the European Economic and Social Committee and the Committee of the Regions Building Trust In EU-Wide Justice a New Dimension To European Judicial Training, COM/2011/0551 final.

Communication from the Commission to the European Parliament, the

Council, the European Economic and Social Committee and the Committee of the Regions A credible enlargement perspective for and enhanced EU engagement with the Western Balkans, Strasbourg, 6.2.2018, $\operatorname{COM}(2018) 65$ final.

Council of Europe, European Charter on the Statute of Judges, 1998, https://rm.coe.int/16807473ef, last visited December 15, 2018.

Council of Europe, European Convention for the Protection of Human

Rights and Fundamental Freedoms, as amended by Protocols Nos.

11 and 14, 4 November 1950, https://rm.coe.int/1680063765, last visited December 15, 2018.

Council of Europe, Recommendation No. (2004) 4 on the European Convention on Human Rights in university education and professional training, https://search.coe.int/cm/Pages/result_details.aspx?ObjectID=09000016805dd13a, last visited December 15, 2018.

Decision on Changes and Amendments to the Rules of Procedure of High Judicial Council, Official Gazette of the Republic of Serbia, No. 29/13. Joined Cases C 397/01 to C 403/01 Pfeiffer and Others [2004] ECR I 8835. Law on High Judicial Council, Official Gazette of the Republic of Serbia, No. 116/2008, 101/2010, 88/2011 and 106/2015.

Law on judges, Official Gazette of the Republic of Serbia, No. 116/2008, 58/2009 - decisions of the Constitutional Court, 104/2009, 101/2010, 8/2012 - decisions of the Constitutional Court, 121/2012, 124/2012 - decisions of the Constitutional Court, 101/2013, 111/2014 - decisions of the Constitutional Court 117/2014, 40/2015, 63/2015 - decisions of the Constitutional Court and 106/2015.

Law on Public Prosecution, Official Gazette of the Republic of Serbia, No. 116/2008, 104/2009, 101/2010, 78/2011 - other law, 101/2011,38/2012 - decisions of the Constitutional Court, 121/2012, 101/2013, 111/2014 decisions of the Constitutional Court, 117/2014 and 106/2015.

Law on State Prosecutorial Council, Official Gazette of the Republic of Serbia, No. 116/2008, 101/2010, 88/2011 and 106/2015.

Opinion No 1 (2001) of The Consultative Council Of European Judges 
(CCJE) for the attention of the Council of Europe on standards concerning the independence of the judiciary and the irremovability of judges (Recommendation no. R (94) 12 on the independence, efficiency and role of judges and the relevance of its standards and any other international standards to current problems in these fields), Strasbourg, 23 November 2001, https://rm.coe. int/1680747830, last visited December 15, 2018.

Opinion No 4 of the Consultative Council of European Judges (CCJE) to the attention of the Committee of Ministers of the Council of Europe on appropriate initial and in-service training for judges at national and European levels, Strasbourg, 27 November 2003, https://rm.coe.int/1680747d37, last visited December 15, 2018.

Opinion no. 3 of the Consultative Council of European Judges (CCJE) to the attention of the Committee of Ministers of the Council of Europe on the principles and rules governing judges' professional conduct, in particular ethics, incompatible behaviour and impartiality, Strasbourg, 19 November 2002, https://rm.coe.int/168070098d, last visited December 15, 2018.

Recommendation $\mathrm{CM} / \operatorname{Rec}(2010) 12$ of the Committee of Ministers to member states on judges: independence, efficiency and responsibilities (Adopted by the Committee of Ministers on 17 November 2010 at the 1098th meeting of the Ministers' Deputies), https:// rm.coe.int/16807096c1, last visited December 15, 2018.

Stabilisation and Association Agreement between the European Communities and their Member States of the one part, and the Republic of Serbia, of the other part.

United Nations, Basic Principles on the Independence of the Judiciary Adopted by the Seventh United Nations Congress on the Prevention of Crime and the Treatment of Offenders held at Milan from 26 August to 6 September 1985 and endorsed by General Assembly resolutions 40/32 of 29 November 1985 and 40/146 of 13 December 1985, https://www.ohchr.org/en/professionalinterest/pages/independencejudiciary.aspx, last visited December 15, 2018.

United Nations, International Covenant on Civil and Political Rights Adopted and opened for signature, ratification and accession by General Assembly resolution 2200A (XXI) of 16 December 1966, entry into force 23 March 1976, in accordance with Article 49, https://www.ohchr.org/Documents/ProfessionalInterest/ccpr.pdf, last visited December 15, 2018. 


\section{Website references}

EJTN, AIAKOS Programme, http://www.ejtn.eu/Exchange-Programme/ Activities/AIAKOS-Programme/, last March 30, 2018.

EJTN, Handbook on Judicial Training Methodology in Europe, www. ejtn.eu/Documents/EJTN_JTM_Handbook_2016.pdf, last visited March 31, 2018.

EJTN, Judicial training principles, http://www.ejtn.eu/PageFiles/15004/Judicial\%20Training\%20Principles_EN.pdf, last visited March 25, 2018.

ERA, Training modules on the European legislative instruments for cross-border cooperation in civil matters, www.era-comm.eu/EU_Civil_Justice_Training_Modules/index_html, last visited April 1, 2018.

European Commission, Final Report - Tender JUST/2 012/JUTR / PR/0064/ A4 Lot 1 "Study on best practices in training of judges and prosecutors", 2014, http://www.ejtn.eu/Documents/Resources/Lot1_final_Jan2015.pdf, last visited March 27, 2018.

European Parliament, Judicial training in the European Union member states, http://www.europarl.europa.eu/RegData/etudes/etudes/join/2011/453198/ IPOL-JURI_ET(2011)453198_EN.pdf, last visited December 15, 2018.

http://ec.europa.eu/environment/legal/law/training_package.htm, last visited March 31, 2018.

http://www.ejtn.eu/Documents/Methodologies_Resources/Best\%20practices\%20Lot\%201\%20EN/ITT_39-I_Hungary_1_EU_en.pdf, last visited December 14, 2018.

http://www.ejtn.eu/Documents/Methodologies_Resources/Best\%20practices\%20Lot\%201\%20EN/ITT_UP\%2003_Romania_EU_en\%20 (2).pdf, last visited December 14, 2018.

http://www.ejtn.eu/Documents/Methodologies_Resources/Best\%20practices\%20Lot\%201\%20EN/ITT_UP\%2002_Portugal_EU_en\%20 (2).pdf, last visited December 14, 2018.

http://www.pars.rs/en/vest/5785/two-day-seminar-entitled-importance-of-theimplementation-of-the-standards-of-the-european-court-of-humanrights-in-the-republic-of-serbia-.php, last visited March 27, 2018.

https://e-justice.europa.eu/content_the_european_judicial_training_policy-121-en.do, last visited April 1, 2018.

https://e-justice.europa.eu/content_training_material-252-en.do?clang=en, last visited March 29, 2018.

https://europeanwesternbalkans.com/2018/05/25/macron-eu-enlargement-cold-water-warm-bath/, last visited December 1, 2018. 
https://www.b92.net/info/vesti/index.php? yyyy $=2017 \& m m=12 \& d$ $d=12 \&$ nav_category $=1262 \& n a v \_i d=1335158$, last visited December 1, 2018.

Knežević Bojović, A. Comparative analysis of judicial training curricula, 2018, https://www.pars.rs/images/projekti/JAP/Komponenta-2/ A4_IIR-Comparative-analysis-of-judicial-training-curricula-Uporedna-analiza-programa-obuke-nosilaca-pravosudnih-funkcija. $p d f$, last visited December 14, 2018.

Nicolaidis, K., Kleinfeld R., Rethinking Europe's 'Rule of Law' and Enlargement Agenda: The Fundamental Dilemma, SIGMA $\mathrm{Pa}$ per No. 49, www.sigmaweb.org/publicationsdocuments/sigma_ sp49_061112_Eng.pdf, last visited March 15, 2018.

Purić, O., Knežević Bojović A. Training needs assessment for the Serbian Judicial Academy Results and recommendations, 2018, https://www. pars.rs/images/projekti/JAP/Komponenta-2/A5_3IR-TNA-for-theSerbian-JA-Results-and-recommendations-no-2-TNA-u-okviru-PAu-RS-br-2--rezulati-i-preporuke.pdf, last visited December 14, 2018. Sofia Declaration, https://www.consilium.europa.eu/media/34776/sofia-declaration_en.pdf, last visited December 1, 2018.

Thomas, C., Review of Judicial Training and Education in Other Jurisdictions, 2006, https://www.ucl.ac.uk/judicial-institute/sites/judicial-institute/files/judicial_training_and_education_in_other_jurisdictions.pdf, last visited October $30,2018$. 


\section{Dr Ana Knežević Bojović}

Naučni saradnik, Institut za uporedno pravo, Beograd

\section{Dr Olivera Purić}

Saradnik, Pravosudna akademija, Beograd

\section{OBUKA SUDIJA I PRAVO EU: POGLED NA UPOREDNOPRAVNU I PRAKSU SRBIJE}

Rezime

Pravo Evropske unije predstavlja ključno pitanje u savremenom obrazovanju sudija u Evropi. Posebno je važno osigurati da pre pristupanja Evropskoj uniji, sudije iz zemalja članica budu adekvatno obučene o osnovama prava EU i o njegovom odnosu sa nacionalnim pravom i ulozi nacionalnog sudije u evropskom sudijskom prostoru. Kada država postane članica EU, potrebno je nastaviti sa adekvatnom obukom i pružanjem podrške sudijama država članica u implementaciji tekovina Evropske unije. Ne postoji ispravan ili pogrešan način na koji se pravo EU može uvesti u sudijsku obuku, iako se mogu identifikovati primeri dobre prakse u državama članicama, kako u onima koje su se relativno skoro pridružile EU, tako i u "starijim" članicama.

Autorke će ispitati praksu u vezi sa sudijskom obukom u pogledu prava EU u Srbiji u svetlu dobre uporednopravne prakse u institucijama za obuku sudija u Evropi i formulisaće preporuke za Srbiju u daljem sprovođenju procesa pristupanja.

Ključne reči: Evropska unija, obuka sudija, nezavisnost, stručnost, uporedna praksa. 